\title{
ROX Index Predicts Intubation in Patients with COVID-19 Pneumonia and Moderate to Severe Hypoxemic Respiratory Failure Receiving High Flow Nasal Therapy.
}

Maulin Patel MD ${ }^{1}$, Junad Chowdhury MD¹, Nicole Mills DO ${ }^{1}$, Robert Marron MD ${ }^{1}$, Andrew Gangemi MD², Zachariah Dorey-Stein MD ${ }^{1}$, Ibraheem Yousef MD ${ }^{1}$, Matthew Zheng MD¹, Lauren Tragesser MS4 ${ }^{2}$, Julie

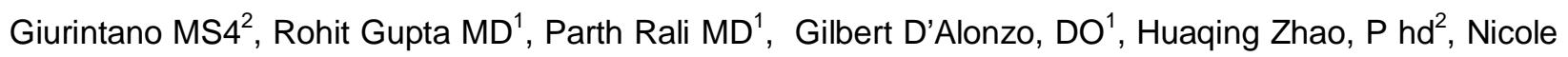
Patlakh $\mathrm{BSc}^{2}$, Nathaniel Marchetti MD ${ }^{1}$, Gerard J. Criner $\mathrm{MD}^{1}$ and Matthew Gordon $\mathrm{MD}^{1}$ for the Temple University COVID-19 Research Group*

1 - Department of Thoracic Medicine and Surgery, Temple University Hospital

2 - Lewis Katz School of Medicine at Temple University.

*- see supplement

None of the authors have any conflict of interest related to the material

\section{Contact Information:}

Maulin Patel, MD

Temple University Hospital, $7^{\text {th }}$ floor Parkinson Pavilion

3401 N Broad St, Philadelphia, PA 19140

maulin.patel@tuhs.temple.edu

Phone \#: 2678582225

Contributions:

Maulin Patel will be the corresponding author and guarantor for the manuscript. Maulin Patel, Matthew Gordon, Junad Chowdhury and Gerard J Criner formulated the overall study design. Huaqing Zhao, Nicole Patlakh, Maulin Patel, Andrew Gangemi, Robert Marron, Junad Chowdhury, Nicole Mills, Zachariah Dorey-Stein, Ibraheem Yousef, Lauren Tragesser, Julie Giurintano assisted in data collection, consolidation and analysis. Maulin Patel, Junad Chowdhury, Parth Rali, Rohit Gupta, Gilbert D'Alonzo and Matthew Gordon drafted the manuscript. Gerard J Criner and Matthew Gordon revised and reviewed the Manuscript

Running head: HFNT in COVID-19 infection, ROX index

Key words: COVID-19, HFNT, respiratory failure, ROX

\section{Summary}

Abstract -279 words

Text -3692 words

References - 1110 words

Tables - 4

Figures -6 


\begin{abstract}
Use of high flow nasal therapy (HFNT) to treat COVID-19 pneumonia has been greatly debated around the world due to concern for increased healthcare worker transmission and delays in invasive mechanical Ventilation (IMV).
\end{abstract}

\title{
Methods
}

A retrospective analysis of consecutive patients admitted to Temple University Hospital in Philadelphia, Pennsylvania, from March 10, 2020, to May 17, 2020 with moderate to severe respiratory failure treated with High Flow nasal therapy (HFNT). HFNT patients were divided into two groups: HFNT only and HFNT progressed to IMV. The primary outcome was the ability of the ROX index to predict the need of IMV.

\section{Results}

Of the 837 patients with COVID-19, 129 met inclusion criteria. The mean age was 60.8 $( \pm 13.6)$ years, BMI $32.6( \pm 8), 58(45 \%)$ were female, $72(55.8 \%)$ were African American, 40 (31\%) Hispanic. 48 (37.2\%) were smokers. Mean time to intubation was 2.5 days $( \pm 3.3)$. ROX index of less than 5 at HFNT initiation was predictive of progression to IMV $(\mathrm{OR}=2 \cdot 137, \mathrm{p}=0,052)$. Any decrease in ROX index after HFNT initiation was predictive of intubation $(\mathrm{OR}=14.67, \mathrm{p}<0.0001)$. $\Delta \mathrm{ROX}(<=0$ versus $>0)$, peak D-dimer $>4000$ and admission GFR $<60 \mathrm{ml} / \mathrm{min}$ were very strongly predictive of need for IMV (ROC $=0.86, p=)$. Mortality was $11.2 \%$ in HFNT only group versus $47.5 \%$ in the HFNT progressed to IMV group ( $p, 0.0001)$. Mortality and need for pulmonary vasodilators were higher in the HNFT progressed to IMV group. 


\section{Conclusion}

ROX index is a valuable, noninvasive tool to evaluate patients with moderate to severe hypoxemic respiratory failure in COVID-19 treated with HFNT. ROX helps predicts need for IMV and thus limiting morbidity and mortality associated with IMV.

\section{Introduction}

December of 2019 was marked by a cluster of acute respiratory illnesses now known as Coronavirus disease 2019 (COVID-19) resulting from severe acute respiratory syndrome-coronavirus-2 (SARS-CoV-2). The virus has infected more than 8.7 million people worldwide with more than 460,000 reported deaths resulting in a worldwide healthcare crisis. ${ }^{1,2}$ The majority of morbidity from COVID-19 arises from severe hypoxemic respiratory failure. As the worldwide pandemic spreads to the farthest reaches of the globe, healthcare centers have been overwhelmed, quickly exhausting their supply of ventilators and personnel trained to manage them. There has been significant controversy regarding the optimal mode of respiratory support to treat COVID-19 associated hypoxemic respiratory failure.

The timing and adequacy of non-invasive forms of oxygen support (i.e. high flow nasal therapy, simple face mask, etc.) versus invasive mechanical ventilation (IMV) is not known. IMV has been associated with significant morbidity and mortality. In some case series, a mortality rate greater than $90 \%$ has been reported. ${ }^{3-6}$ Case series from China, Italy and New York had intubation rates ranging from $20.2 \%$ to $88 \%{ }^{4,6-9}$ Early utilization of IMV has been greatly influenced by concerns of viral aerosolization and subsequently health care transmission through the use of non-invasive forms of oxygen 
support. $^{10}$ In addition, rapid progression of hypoxemic respiratory failure from mild dyspnea to ARDS within 48-72 hours were noted in early studies. ${ }^{9,11}$ Consequently, some centers preemptively intubate patients with oxygen requirements as low as 6 liters-per-minute (LPM) of oxygen via nasal cannula for prolonged periods. ${ }^{3}$

High flow nasal therapy (HFNT), in contrast to IMV, is a non-invasive oxygen system that delivers humidified air-oxygen blends and a titratable fraction of inspired oxygen $\left(\mathrm{F}_{1} \mathrm{O}_{2}\right)$ as high as $60 \mathrm{LPM}$ and $100 \% \mathrm{~F}_{1} \mathrm{O}_{2}$ respectively. Despite proven efficacy in other disease processes, the utilization of HFNT has been limited and its use has not been widely recommended for use in patients with COVID-19 pneumonia and hypoxemic respiratory failure. Limitations to adoption include concerns about rapid progression of disease as well as fearing aerosolization of the COVID-19 virus resulting in increased transmission to healthcare providers. ${ }^{12-14}$

However, HFNT has been successfully used in severe viral respiratory illnesses including influenza $\mathrm{A}$ and $\mathrm{H} 1 \mathrm{~N} 1 .{ }^{15} \mathrm{HFNT}$ reduces the need for invasive mechanical ventilation rates compared to other modalities, with some studies also showing reduced 90-day mortality. ${ }^{16-19}$ By decreasing the incidence of invasive ventilation, HFNT has the potential to decrease complications associated with IMV such as the incidence of ventilator-associated pneumonia (VAP). When compared with noninvasive ventilation (NIV) and conventional oxygen therapy, the use of HFNT has also shown to reduce rates of reintubation due to post-extubation respiratory failure and has much better tolerability than NIV. ${ }^{20,21}$ The Surviving Sepsis Guidelines for COVID-19 also recommends using HFNT in patients with acute hypoxemic respiratory failure due to COVID-19. ${ }^{22}$ 
medRxiv preprint doi: https://doi.org/10.1101/2020.06.30.20143867; this version posted July 3, 2020. The copyright holder for this preprint (which was not certified by peer review) is the author/funder, who has granted medRxiv a license to display the preprint in perpetuity. It is made available under a CC-BY-NC-ND 4.0 International license .

The ROX index, defined as the ratio of oxygen saturation as measured by pulse oximetry $(\mathrm{SpO} 2) / \mathrm{FiO} 2$ to respiratory rate $(\mathrm{RR})$ in breaths per minute, is a validated measurement that predicts outcomes when using HFNT to treat hypoxemic respiratory failure. A ROX index $<4.88$ after 12 hours predicts the need for IMV in patients with pneumonia. $^{23}$

Herein we analyze the utility of the ROX index to predict the need and timing for IMV in a retrospective analysis of 129 patients with COVID-19 associated with moderate to severe hypoxemic respiratory failure treated with HFNT. In addition, mortality, rates of intubation, length of stay (LOS) and rates of nosocomial infections in our cohort treated with HFNT were also reported.

\section{Methods}

The study was approved by the Temple University Institutional Review Board (TU-IRB protocol number: 27051). A waiver of consent was granted due to the acknowledged minimal risk to the patients.

A retrospective analysis of 1397 consecutive patients admitted to Temple University Hospital in Philadelphia, Pennsylvania, from March 10, 2020, to May 17, 202 was performed. Initial screening included all patients who had tested positive for COVID-19 using nasopharyngeal real time reverse transcriptase PCR (RT-PCR) or had high clinical suspicion based on high-resolution computerized tomography (HRCT) of the chest (typical peripheral nodular or ground glass opacities without alternative cause $)^{24}$ with typical inflammatory biomarker profile and a suggestive clinical history. 
medRxiv preprint doi: https://doi.org/10.1101/2020.06.30.20143867; this version posted July 3, 2020. The copyright holder for this preprint (which was not certified by peer review) is the author/funder, who has granted medRxiv a license to display the preprint in perpetuity. It is made available under a CC-BY-NC-ND 4.0 International license.

All patients with moderate to severe hypoxemic respiratory failure who were treated with HFNT at any point during the hospitalization were included in the study. Moderate and severe hypoxemic respiratory failure was defined as hypoxemia requiring more than $6 \mathrm{~L} /$ min of oxygen via nasal cannula. Absence of HFNT during hospitalization was an exclusion criterion.

\section{Laboratory data}

Demographics including age, sex, comorbidities, body mass index (BMI), and smoking status (current smoker, non-smoker) were collected. In addition, laboratory biomarkers on admission including complete blood count (CBC) with differential, ferritin, fibrinogen, lactate dehydrogenase (LDH), D-dimer, and C-reactive protein (CRP) were analyzed.

\section{Respiratory Metrics}

Respiratory metrics at the initiation of HFNT included respiratory rate (RR), pulse oximetry, and fraction of inspired oxygen $\left(\mathrm{F}_{1} \mathrm{O}_{2}\right)$. The same parameters were collected at days $1,2,3$ and 5 post-initiation of HFNT. Parameters were recorded at the lowest $\mathrm{F}_{1} \mathrm{O}_{2}$ and highest pulse oximetry reported for the day. For patients who required IMV prior to the conclusion of data collection, respiratory parameters on the day of intubation were reported. Days on HFNT therapy, time to intubation (in days), average flow rate on HFNT, and the presence of hospital acquired pneumonia (HAP)/Ventilator associated Pneumonia (VAP) were also reported. 
medRxiv preprint doi: https://doi.org/10.1101/2020.06.30.20143867; this version posted July 3, 2020. The copyright holder for this preprint (which was not certified by peer review) is the author/funder, who has granted medRxiv a license to display the preprint in perpetuity.

\section{Respiratory therapy}

HFNT was provided with a humidified air-oxygen blender starting at 35 LPM with the fraction of inspired oxygen $\left(\mathrm{F}_{1} \mathrm{O}_{2}\right)$ adjusted to maintain oxygen saturations $\geq 92 \%$; further adjustments were made based on patients' tolerance and goals of oxygenation. The initial temperature for the high flow setup was $37^{\circ} \mathrm{C}$ and was titrated between 34$37^{0} \mathrm{C}$ for patient comfort. As an institutional policy, HFNT was preferred over IMV and was maintained indefinitely as long as oxygenation, ventilation, and work of breathing parameters were acceptable. Data on initial oxygenation support included flow of airoxygen blend in LPM and $\mathrm{F}_{1} \mathrm{O}_{2}$. The decision to switch to NIV or IMV was at the discretion of the clinical care team. Once on IMV, patients were assessed daily for appropriateness of spontaneous breathing trials (SBT) and spontaneous awakening trials (SAT) for extubation per standard guidelines. Patients were extubated following a SBT of $15-30$ minutes on either pressure support ventilation (PSV) of $5 \mathrm{cmH}_{2} \mathrm{O}$ or Tpiece with a viral filter based on clinical judgement and rapid shallow breathing index.

\section{Institutional Approach to COVID-19 Directed Therapies}

All patients admitted due to respiratory symptoms and classic radiographic evidence of COVID-19 pneumonia were admitted to a specialized hospital unit and given antibiotic therapy for community acquired pneumonia and systemic steroids with methylprednisolone at 0.5 to $1.0 \mathrm{~m} / \mathrm{kg}$ for at least $5-10$ days. Patients with RT-PCR positive swabs were also screened for eligibility for randomized controlled trials at our institution which included sarilumab (Regeneron Pharmaceuticals; NCT04315298), remdesivir (Gilead Sciences; NCT04292730 and NCT04292899), gimsilumab (Kinevant 
medRxiv preprint doi: https://doi.org/10.1101/2020.06.30.20143867; this version posted July 3, 2020. The copyright holder for this preprint (which was not certified by peer review) is the author/funder, who has granted medRxiv a license to display the preprint in perpetuity. It is made available under a CC-BY-NC-ND 4.0 International license .

Sciences: NCT04351243), and convalescent plasma (Mayo Clinic; NCT04338360).

Those with significant disease, but ineligible for clinical trials were treated with compassionate use of anakinra, tocilizumab or etoposide based on institutional care pathways. Other therapies included high-dose corticosteroids (defined as a minimum daily $125 \mathrm{mg}$ of methylprednisolone and above, regardless of bolus frequency), intravenous immunoglobulin (IVIG), and hydroxychloroquine (HCQ). Therapies were offered based on clinical severity, radiographic burden, and/or presence of cytokine storm as evidenced by inflammatory markers. The decision to select from these choices was made by the same institutional multidisciplinary team including pulmonologists and rheumatologists.

\section{Outcomes}

The primary outcome was the ability of the ROX index to predict the need of IMV. Secondary outcomes include mortality, hospital length of stay (LOS) and hospital/ventilator acquired pneumonia. Hospital and ventilator acquired pneumonia was defined based on the presence of sputum positivity and treatment with antibiotics.

Our patients were divided into two groups: 1) HFNT support as a bridge to recovery (HFNT group) and 2) HFNT with progression to IMV (i.e., intubation group) for analysis. Comparison was made between demographics, baseline laboratory values, and outcomes within the two groups. Changes in ROX index and concomitant changes in clinical parameters of heart rate $(\mathrm{HR})$ were also analyzed.

A multivariable prediction model for intubation for our cohort based on the above parameters was created. ROX index, comorbidities, clinical and laboratory data were 
medRxiv preprint doi: https://doi.org/10.1101/2020.06.30.20143867; this version posted July 3, 2020. The copyright holder for this preprint (which was not certified by peer review) is the author/funder, who has granted medRxiv a license to display the preprint in perpetuity. It is made available under a CC-BY-NC-ND 4.0 International license .

used to identify parameters that could predict the need for intubation. A ROC curve was going to be generated to determine accuracy of the model.

\section{Statistical methods}

Continuous variables are presented as means ( \pm standard deviation), and categorical variables as numbers and Frequency (percentages). Continuous variables were compared with the use of the two-sample t-test or paired t-test for categorical variables with the use of the Pearson chi-square test. Laboratory data were nonparametric and compared using Wilcox Rank-Sum test. Kaplan-Meier analysis was estimated for survival and compared by log-rank test.

To build a predictive model of the intubation, multivariable logistic regression was performed to determine the adjusted associations of the variables with intubation. The initial model included all the variables associated with intubation in univariate analyses for $p<0.1$. The final model that optimized the balance of the fewest variables with good predictive performance. Assessment of model performance was based on discrimination and calibration. Discrimination was evaluated using the C-statistic, which represents the area under the receiver operating characteristic (ROC) curve, where higher values represent better discrimination. Calibration was assessed by the HosmerLemeshow test, where a p-value greater than 0.05 indicates adequate calibration.

All statistical tests were two-tailed, and $P$ values of less than 0.05 were considered to indicate statistical significance. All statistical analyses were performed with the use of Stata 14.0 (StataCorp LP, College Station, TX). 
Results

Patient population

1,397 patients admitted to Temple University Hospital between March 10, 2020, and May 17, 2020 were screened. Of these, 837 patients had tested positive for COVID-19 by nasopharyngeal RT-PCR or were treated for high clinical suspicion based on typical CT imaging and inflammatory biomarker profile. 388 patients had hypoxemic respiratory failure. 129 (15.4\%) patients met our inclusion criteria of being on High flow nasal therapy (HFNT) with moderate to severe hypoxemic respiratory failure (Figure 1).

Demographics

The mean age was $60.8( \pm 13.6)$ years, BMI $32.6(8), 58$ (45\%) were female, 72 (55.8\%) were African American, 40 (31\%) Hispanic. 48 (37.2\%) were smokers. The major comorbidities reported (in descending incidence) were hypertension, diabetes, lung disease, heart disease, chronic kidney disease (CKD), malignancy and psychiatric illness (Table 1). There were no differences in age, BMI and gender between the groups. There were more smokers in the intubation group at $55 \%$ compared to $29.2 \%$. There was a trend towards a higher incidence of lung disease, CKD, malignancy and psychiatric disorders in the intubation group.

\section{Treatments}

Azithromycin (70.2\%) and steroids (86\%) were the most frequently utilized therapies. Immunomodulator therapy including sarilumab, anakinra, IVIG and tocilizumab were the next most commonly used therapies. There was a higher usage of 
medRxiv preprint doi: https://doi.org/10.1101/2020.06.30.20143867; this version posted July 3, 2020. The copyright holder for this preprint (which was not certified by peer review) is the author/funder, who has granted medRxiv a license to display the preprint in perpetuity. It is made available under a CC-BY-NC-ND 4.0 International license .

gimsilumab, hydroxychloroquine, IVIG, tocilizumab and etoposide in the intubation group, while azithromycin was higher in the HFNT only group. Steroid usage and other immunomodulators were similar across the groups.

\section{Laboratory markers}

Elevated inflammatory markers (i.e., ferritin, CRP, D-dimer, fibrinogen, LDH, IL6), transaminitis and lymphopenia were observed in all patients. There was a trend towards higher inflammatory markers (i.e., ferritin, CRP, LDH, D-dimer, IL-6, IL-1), triglycerides and transaminases in the intubation group. Statistically significant higher creatinine and lower GFR were seen in the intubation group.

\section{Respiratory parameters}

Mean admission S-F ratio was $294.7 \pm 131.6$ and was statistically different between the groups $(313.3 \pm 125.6$ vs. $252.2 \pm 136.8)$. S-F ratio at high flow initiation was $121.1 \pm 38.4$ overall, with no statistically significant differences in the groups (HFNT group $124.4 \pm 38.8)$ vs intubation group $(113.8 \pm 37)$. The mean corresponding P-F ratio at start of HFNT was $\sim 100$.

Initial HFNT settings were $33.5 \pm 11.7 \mathrm{~L} / \mathrm{min}$ of flow, while $\mathrm{F}_{\mathrm{l}} \mathrm{O}_{2}$ was $84.1 \% \pm 20.3$. The intubation group had a statistically higher flow rate than the HFNT group. The average use of HFNT for our population was 5.6 days \pm 5.1 . The minimum settings on HFNT were $10 \mathrm{~L}$ flow and $\mathrm{F}_{1} \mathrm{O}_{2}$ of $30 \%$, while the maximum settings were $60 \mathrm{~L}$ and $\mathrm{F}_{1} \mathrm{O}_{2}$ of $100 \%$. The major complication with use of HFNT was progression to IMV or NIV which was seen in $40(31.0 \%)$ patients. Average ventilator days were $10.2 \pm 7.6$ days. 10 
medRxiv preprint doi: https://doi.org/10.1101/2020.06.30.20143867; this version posted July 3, 2020. The copyright holder for this preprint (which was not certified by peer review) is the author/funder, who has granted medRxiv a license to display the preprint in perpetuity. It is made available under a CC-BY-NC-ND 4.0 International license .

(27.5\%) patients received a tracheostomy. Overall, 46 patients required pulmonary vasodilators, with statistically higher usage in the intubation group.

Outcomes

ROX index trends

Mean ROX index for the total cohort was $5.1 \pm 2.0$ at HFNT initiation, $5.9 \pm 2.5,6.9$ $\pm 3.9,8.1 \pm 4.1$ and $10.3 \pm 5.9$ on day $1,2,3$ and 5 respectively. The mean ROX index consistently improved from initiation to day 5 in the HFNT group, while staying constant in the intubation group (Figure 2). At each time interval, the ROX index was significantly higher in the HFNT group compared to the intubation group. The ROX change per day was also statistically different between the groups: $(1.2 \pm 1.3)$ in the HFNT group vs. $(-0.3$ \pm 1.2 ) in the intubation group). ROX before intubation was the lowest at $3.4 \pm 1.0$ (Table 2).

\section{Secondary Outcomes}

Overall, mortality at our institution was $6.06 \%$ for patients positive for COVID-19 infection. However, in this cohort of severe hypoxemic respiratory failure, our mortality was $22.5 \%$, with $11.2 \%$ in the HFNT group and $47.5 \%$ in the intubation group. Figure 3 shows the Kaplan Meir curve between two groups for survival. Of the 10 deaths in the HFNT group, 6 patients were in hospice care while the remaining were Do not resuscitate/intubate (DNR/DNI). Average LOS was statistically higher in the intubation group (11.1 days in the HFNT group vs. 19.5 days in the intubation group) (Table 3). 
medRxiv preprint doi: https://doi.org/10.1101/2020.06.30.20143867; this version posted July 3, 2020. The copyright holder for this preprint (which was not certified by peer review) is the author/funder, who has granted medRxiv a license to display the preprint in perpetuity. It is made available under a CC-BY-NC-ND 4.0 International license .

The overall incidence of hospital acquired pneumonia was significantly higher in the intubation group $(25 \%$ vs $1.1 \%, p=0.0001)$

\section{Prediction Model}

At initiation of HFNC, a ROX of $<5$ was predictive of intubation $(\mathrm{OR}=2.137$, $\mathrm{p}=0.051$ ). Any change in ROX of less than or equal to zero after HFNT initiation over 24 hours was also predictive of intubation $(O R=14.67, p<0.0001)$. A decrease in ROX by 1 over 24 hours regardless of ROX index value was strongly predictive of intubation $(\mathrm{OR}=5, \mathrm{p}<0.0001)$ (Table 4). Figure 4 shows intubation free survival based on ROX change ( $<=0$ versus $>0$ ) per 24 hours. In the univariate analysis, smoking, history of malignancy, admission LDH > 500, peak D-dimer greater than 4000, peak Ferritin > 1000, Peak CRP >= 10, peak LDH > 500, ROX decrease as described above, admission triglycerides $>200$, and a glomerular filtration rate $<60$ were all predictive of intubation (See supplementary Table 1). In a multivariate model, unchanged and/or decreased ROX over 24 hours, peak D-dimer greater than 4000 and GFR less than 60 $\mathrm{ml} / \mathrm{min}$ were predictive of intubation (Table 4). Figure 5 and 6 show the receiver operator curve for ROX change over 24 hours $(\mathrm{ROC}=0.77)$ and the multivariate model respectively $(\mathrm{ROC}=0.86)$.

\section{Discussion}

In this retrospective review of patients with acute hypoxemic respiratory failure secondary to COVID-19 pneumonia, 129 patients were initially treated with HFNT. Out of this cohort, 89 patients remained on HFNT while 40 patients eventually required IMV. 
medRxiv preprint doi: https://doi.org/10.1101/2020.06.30.20143867; this version posted July 3, 2020. The copyright holder for this preprint (which was not certified by peer review) is the author/funder, who has granted medRxiv a license to display the preprint in perpetuity. It is made available under a CC-BY-NC-ND 4.0 International license .

The 89 patients successfully treated with HFNT as a bridge to recovery had a significant improvement in ROX from initiation of HFNT at all recorded time points. In contrast, the ROX score for patients that ultimately required intubation remained steady or decreased over time.

A decrease in ROX score of 1 over any 24-hour period increases the likelihood of intubation 5 -fold $(O R=5, p<0.0001)$, regardless of ROX value at HFNT initiation. When compared to the baseline ROX score at HFNT initiation, failure of the ROX score to improve $(\Delta \mathrm{ROX} \leq 0)$ increases the likelihood of intubation by a factor of $15(\mathrm{OR}=$ $14.67, p<0.0001)$. Lastly, a combination of change in ROX index, GFR $<60$ and peak Ddimer $>4000$ were even more predictive of intubation. Mortality and LOS in the HFNT group was significantly lower than the intubation group and the incidence of hospitalacquired pneumonia was higher in the intubation group. There were no associated deaths peri-intubation despite the presence of significant hypoxemia. There were no reported cases of failure to intubate resulting in adverse outcome. Overall, the intubation group had a higher incidence of lung disease, chronic kidney disease, smoking, and malignancy.

HFNT is an important oxygen delivery modality that can help reduce intubation as seen by our overall institution intubation rate of $10 \%$, significantly lower than the reported literature. ${ }^{4,6,7}$ Moreover, there may be a survival benefit with HFNT therapy in COVID-19 as seen in prior acute hypoxemic respiratory failure studies. ${ }^{13,25}$ Despite our patient population having a higher incidence of lung disease and nicotine exposure than that reported in previous studies, the mortality rate was $22 \%$, which is lower than prior reports. $^{4,6,11}$. 
medRxiv preprint doi: https://doi.org/10.1101/2020.06.30.20143867; this version posted July 3, 2020. The copyright holder for this preprint (which was not certified by peer review) is the author/funder, who has granted medRxiv a license to display the preprint in perpetuity. It is made available under a CC-BY-NC-ND 4.0 International license .

Gattinoni and colleagues proposed that COVID-19 patients fall into two distinct groups or phenotypes. The "Type L" or "non-ARDS Type 1" phenotype has low elastance and high compliance. These patients often present with profound hypoxemia and low lung recruitability. As opposed to this the "Type H" or "ARDS Type 2" phenotype have high elastance and low compliance, requiring traditional management strategies of higher PEEP and lower tidal volumes. ${ }^{26,27}$ A significant number of COVID19 patients present with silent hypoxemia. As HFNT provides a modest PEEP effect (i.e. $3-5 \mathrm{cmH}_{2} \mathrm{O}$ at flow rates of $30-50$ LPM with mouth closed) ${ }^{28}$ patients with predominant Type L physiology may benefit from the oxygenation support that HFNC can provide noninvasively. HFNT also leads to a high oxygen reservoir by reducing anatomical dead space in the nasopharynx. ${ }^{29}$ Often, higher tidal volumes are employed in type-L phenotype which can lead to ventilator associated lung injury (VILI). VILI can cause inflammatory cytokine release in ARDS patients, including IL-6, both in critically ill humans. ${ }^{30,31} \mathrm{IL}-6$ in particular is one of the pathologic mechanisms for lung injury in COVID-19. ${ }^{32,33}$ Thus, use of HFNT should not be overlooked in patients with severe COVID-19 respiratory failure.

Patient self-induced Lung injury (P-SILI) has been cited as a theoretical contraindication to noninvasive methods of oxygenation. To date however, P-SILI remains a conceptual model concept compared to VILI. ${ }^{34,35}$

Optimal timing of IMV remains a point of debate, especially in patients previously supported with noninvasive forms of oxygen support, especially with regards to COVID19. Based on our results, any decrease in ROX index over a 24-hour period from baseline ROX at HFNT initiation is a strong predictor of intubation, irrespective of total 
number of HFNT days. We choose to design ROX change as $\leq 0$ vs. $>0$ for ease of use in the acute care setting.

Roca et al previously used a ROX index of $<4.8$ at 12 hours to successfully identify patients with high risk for intubation amongst a cohort of 191 patients treated with HFNC for acute hypoxemic respiratory failure secondary to pneumonia. ${ }^{23,36}$ Our analysis further validates their findings in the setting of viral pneumonia as opposed to predominantly bacterial pneumonia as was reported in their study. Our receiver operator analysis yielded similar results to initial studies. Thus, using serial measurements, we can easily identify patients on HFNT therapy in whom IMV should be considered based on changes in ROX. ${ }^{37}$

Theoretically, the ROX can easily identify patients shifting from L-phenotype to H-phenotype (lower SF ratios and higher respiratory drive), thus minimizing subsequent risks of P-SILI. Another advantage of using the ROX index is its noninvasive nature based on readily available clinical parameters. The ROX index can be calculated remotely, thus preserving personal protective equipment and limiting healthcare exposure. When combined with a decreasing ROX index, a GFR $<60$ and D-dimer $>4000$ stratifies high risk patients with increased accuracy. Kidney dysfunction makes patients susceptible to even small fluid shifts, thus worsening hypoxemia. D-dimer > 4000 might possibly be a sign of micro thrombi in pulmonary circulation described in COVID-19. ${ }^{38}$

Viral transmission through aerosolization by non-invasive forms of oxygenation such as HFNT remains controversial and is much debated. During the SARS outbreak 
medRxiv preprint doi: https://doi.org/10.1101/2020.06.30.20143867; this version posted July 3, 2020. The copyright holder for this preprint (which was not certified by peer review) is the author/funder, who has granted medRxiv a license to display the preprint in perpetuity. It is made available under a CC-BY-NC-ND 4.0 International license .

in 2003, transmission to healthcare workers was reported from only $8 \%$ of HFNT patients. ${ }^{39}$ This was demonstrated in further studies that proved that bacterial environmental contamination was not increased in the setting of HFNT use. ${ }^{40}$ An in-vitro study mimicking clinical scenarios including HFNT with mannequins only revealed proximal dispersion of secretions to the face and nasal cannula itself. ${ }^{41,42} \mathrm{~A}$ recent study with healthy volunteers wearing high-flow nasal cannulas at both $30 \mathrm{~L} / \mathrm{min}$ and $60 \mathrm{~L} / \mathrm{min}$ of gas flow did not report variable aerosolization of particles between 10-10,000 nm, regardless of coughing, when compared with patients on room air or oxygen via regular nasal cannula. ${ }^{43}$ At an institution with dedicated COVID-19 wards, only 1 of 80 staff members in our department had suspicion of health care transmission while directly caring for COVID-19 patients, thus reemphasizing that HFNT did not present an increased risk of healthcare transmission.

Our study has several strengths. It is the largest reported cohort utilizing HFNT in COVID-19 thus far. The ROX index was able to successfully predict bridge to recovery or progression to IMV without demonstrable adverse effect from delaying implementation of mechanical ventilation. In a high-risk, urban population with multiple comorbidities, use of HFNT resulted in a lower rate of intubation, and suggests a possible mortality benefit while maintaining a low risk of healthcare transmission.

Our study has several limitations. First, it is a retrospective review, thus making it susceptible to unintended biases. Developing a prospective study during a pandemic situation was impractical. Secondly, although this is the largest HFNT study, the total N is limited and representative of a singles center's experience. Lastly, we were unable to 
medRxiv preprint doi: https://doi.org/10.1101/2020.06.30.20143867; this version posted July 3, 2020. The copyright holder for this preprint (which was not certified by peer review) is the author/funder, who has granted medRxiv a license to display the preprint in perpetuity. It is made available under a CC-BY-NC-ND 4.0 International license.

provide consistent details on the presence and degree of hypercapnia for our cohort due to our institutional policy to minimize staff exposure to COVID-19 infection.

In conclusion, the ROX index provides an accurate risk stratification tool in patients with moderate to severe hypoxemic respiratory failure secondary to COVID-19 pneumonia. HFNT can be safely and successfully implemented while utilizing the ROX index to predict the need for IMV. Monitoring ROX trends may allow clinicians to avoid any significant delays in escalating the level of care or implementing IMV. Use of HFNT not only reduces intubation rates, but also has the potential to reduce mortality and morbidity associated with IMV. 
medRxiv preprint doi: https://doi.org/10.1101/2020.06.30.20143867; this version posted July 3, 2020. The copyright holder for this preprint (which was not certified by peer review) is the author/funder, who has granted medRxiv a license to display the preprint in perpetuity.

Figures and Tables

Table 1: Baseline Demographics comparing HFNT group with HFNT progressed to IMV group

\begin{tabular}{|c|c|c|c|c|}
\hline & Total $(\mathrm{N}=129)$ & $\begin{array}{l}\text { HFNT only } \\
\quad(\mathrm{N}=89)\end{array}$ & $\begin{array}{l}\text { HFNT } \\
\text { progressed to } \\
\text { IMV }(\mathrm{N}=40)\end{array}$ & P-value \\
\hline \multicolumn{5}{|c|}{ Demographics } \\
\hline Age (years) & $60.8(13.6)$ & $60.7(14.0)$ & $61.2(12.9)$ & 0.855 \\
\hline $\mathrm{BMI}^{\star}(\mathrm{kg} / \mathrm{m} 2)$ & $32.6(8.0)$ & $32.7(8.0)$ & $32.3(8.0)$ & 0.798 \\
\hline $\begin{array}{c}\text { Gender } \\
\text { Female } \\
\text { Male }\end{array}$ & $\begin{array}{l}58(45.0) \\
71(55.0)\end{array}$ & $\begin{array}{l}43(48.3) \\
46(51.7)\end{array}$ & $\begin{array}{l}15(37.5) \\
25(62.5)\end{array}$ & 0.253 \\
\hline $\begin{array}{l}\text { Race } \\
\text { Black } \\
\text { Caucasian } \\
\text { Hispanic } \\
\text { Other/Unknown }\end{array}$ & $\begin{array}{c}72(55.8) \\
12(9.3) \\
40(31.0) \\
5(3.9)\end{array}$ & $\begin{aligned} 51 & (57.3) \\
5 & (5.6) \\
28 & (31.5) \\
5 & (5.6)\end{aligned}$ & $\begin{array}{l}21(52.5) \\
7(17.5) \\
12(30.0) \\
0(0.0)\end{array}$ & 0.087 \\
\hline $\begin{array}{l}\text { Smoking } \\
\text { Non-smoker } \\
\text { Smoker } \\
\text { Unknown }\end{array}$ & $\begin{array}{c}72(55.8) \\
48(37.2) \\
9(7.0)\end{array}$ & $\begin{array}{c}58(65.2) \\
26(29.2) \\
5(5.6)\end{array}$ & $\begin{array}{c}14(35.0) \\
22(55.0) \\
4(10.0)\end{array}$ & 0.006 \\
\hline $\begin{array}{l}\text { Co-morbidities } \\
\text { Lung Disease } \\
\text { Hypertension } \\
\text { Heart Disease } \\
\text { DM* }^{\star} \\
\text { CKD}^{\star} \\
\text { Psych disease } \\
\text { Malignancy }\end{array}$ & $\begin{array}{l}38(29.7) \\
85(65.9) \\
33(25.6) \\
59(45.7) \\
23(17.8) \\
10(7.9) \\
15(11.7)\end{array}$ & $\begin{array}{c}23(26.1) \\
59(66.3) \\
22(24.7) \\
44(49.4) \\
13(14.6) \\
4(4.6) \\
4(4.5)\end{array}$ & $\begin{array}{l}15(37.5) \\
26(65.0) \\
11(27.5) \\
15(37.5) \\
10(25.0) \\
6(15.0) \\
11(27.5)\end{array}$ & $\begin{array}{l}0.192 \\
0.886 \\
0.738 \\
0.208 \\
0.154 \\
0.043 \\
0.0002\end{array}$ \\
\hline \multicolumn{5}{|l|}{ Treatments } \\
\hline $\begin{array}{l}\text { Remdesivir } \\
\text { Sarilumab } \\
\text { Anakinra } \\
\text { Tocilizumab } \\
\text { Etoposide } \\
\text { IVIG* } \\
\text { Pulse Steroids } \\
\text { HCQ* }^{\star} \\
\text { Gimsilumab }\end{array}$ & $\begin{array}{c}11(8.5) \\
61(47.3) \\
17(13.2) \\
24(18.6) \\
2(1.6) \\
38(29.5) \\
111(86.0) \\
11(8.5) \\
13(10.1)\end{array}$ & $\begin{aligned} & (7.9) \\
49 & (55.1) \\
13 & (14.6) \\
14 & (15.7) \\
0 & (0.0) \\
21 & (23.6) \\
75 & (84.3) \\
6 & (6.7) \\
7 & (7.9)\end{aligned}$ & $\begin{array}{c}4(10.0) \\
12(30.0) \\
4(10.0) \\
10(25.0) \\
2(5.0) \\
17(42.5) \\
36(90.0) \\
5(12.5) \\
6(15.0)\end{array}$ & $\begin{array}{l}0.688 \\
0.008 \\
0.474 \\
0.211 \\
0.033 \\
0.029 \\
0.385 \\
0.279 \\
0.213\end{array}$ \\
\hline
\end{tabular}


medRxiv preprint doi: https://doi.org/10.1101/2020.06.30.20143867; this version posted July 3, 2020. The copyright holder for this preprint (which was not certified by peer review) is the author/funder, who has granted medRxiv a license to display the preprint in perpetuity.

It is made available under a CC-BY-NC-ND 4.0 International license .

\begin{tabular}{|c|c|c|c|c|}
\hline $\begin{array}{l}\text { Plasma } \\
\text { Azithromycin }\end{array}$ & $\begin{array}{l}15(11.6) \\
73(70.2)\end{array}$ & $\begin{array}{c}9(10.1) \\
53(73.6)\end{array}$ & $\begin{array}{c}6(15.0) \\
20(62.5)\end{array}$ & $\begin{array}{l}0.423 \\
0.253\end{array}$ \\
\hline \multicolumn{5}{|c|}{ Admission Laboratory markers } \\
\hline 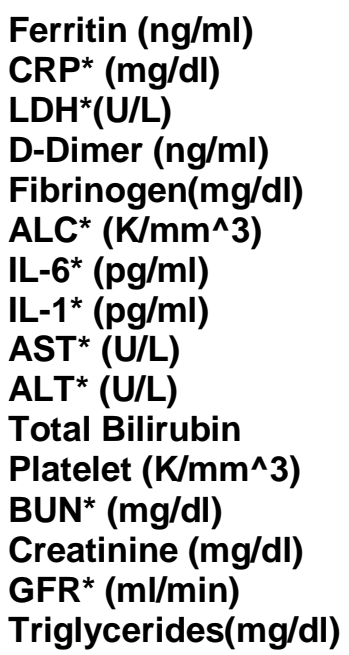 & $\begin{array}{c}1193.5(2490.9) \\
11.4(8.0) \\
425.3(254.7) \\
4719.6(14244.6) \\
519.6(185.0) \\
1.4(2.9) \\
743.1(5026.8) \\
2.6(3.9) \\
58.5(71.9) \\
41.8(35.0) \\
0.9(1.1) \\
215.4(97.9) \\
29.1(26.2) \\
2.5(3.9) \\
60.1(32.7) \\
166.7(165.1)\end{array}$ & $\begin{array}{c}939.8(1232.6) \\
10.9(7.4) \\
401.4(255.4) \\
3465.7(10618.9) \\
532.1(158.1) \\
1.1(0.8) \\
34.7(45.9) \\
2.1(0.5) \\
49.5(35.3) \\
40.0(24.2) \\
0.8(1.1) \\
219.5(103.2) \\
26.3(24.9) \\
2.1(3.9) \\
66.6(31.6) \\
143.2(87.0)\end{array}$ & $\begin{array}{c}1751.8(4043.6) \\
12.5(9.0) \\
478.5(248.2) \\
7509.5(19998.8) \\
492.5(233.4) \\
2.2(5.1) \\
1634.2(7526.2) \\
3.4(6.0) \\
79.0(117.1) \\
45.9(51.8) \\
1.2(0.9) \\
206.1(84.9) \\
35.3(28.2) \\
3.3(3.8) \\
45.4(30.5) \\
213.8(253.8)\end{array}$ & $\begin{array}{l}0.220 \\
0.303 \\
0.112 \\
0.234 \\
0.340 \\
0.170 \\
0.246 \\
0.304 \\
0.136 \\
0.494 \\
0.026 \\
0.482 \\
0.071 \\
0.0004 \\
0.0005 \\
0.095\end{array}$ \\
\hline \multicolumn{5}{|c|}{ Respiratory Parameters } \\
\hline $\begin{array}{l}\text { HFNT Days } \\
\text { HFNT flow rate } \\
\text { SF }^{\star} \text { admission } \\
\text { SF}^{\star} \text { HFNT start } \\
\text { ROX HFNT start } \\
\text { PV }^{\star} \\
\text { Ventilator days } \\
\text { Tracheostomy }\end{array}$ & $\begin{array}{c}5.6(5.1) \\
33.5(11.7) \\
294.7(131.6) \\
121.1(38.4) \\
5.1(2) \\
46(35.7) \\
10.2(7.6) \\
11(27.5)\end{array}$ & $\begin{array}{c}6.6(5.5) \\
31.5(9.7) \\
313.3(125.6) \\
124.4(38.8) \\
5.4(2.1) \\
25(28.1) \\
- \\
-\end{array}$ & $\begin{array}{c}3.2(3.1) \\
38.2(14.6) \\
252.2(136.8) \\
113.8(37) \\
4.5(1.6) \\
21(52.5) \\
10.2(7.6) \\
11(27.5)\end{array}$ & $\begin{array}{c}0.0001 \\
0.012 \\
0.015 \\
0.150 \\
0.015 \\
0.007 \\
\text { N/A } \\
\text { N/A }\end{array}$ \\
\hline
\end{tabular}

${ }^{*}$ BMI-body mass index, DM- diabetes mellitus, CKD- Chronic kidney disease, IVIG- intravenous immunoglobulin, HCQ - hydroxychloroquine, CRP - C reactive protein, $\mathrm{LDH}$ - lactate dehydrogenase, ALC - absolute lymphocyte count, IL-6 - interleukin 6, IL-1 - interleukin 1, AST - aspartate Aminotransferase, ALT- Alanine Aminotransferase, BUN - blood urea nitrogen, GFR - glomerular filtration rate, SF - ratio of oxygen saturation to fraction of inspired oxygen, PV- pulmonary vasodilators 
medRxiv preprint doi: https://doi.org/10.1101/2020.06.30.20143867; this version posted July 3, 2020. The copyright holder for this preprint (which was not certified by peer review) is the author/funder, who has granted medRxiv a license to display the preprint in perpetuity.

It is made available under a CC-BY-NC-ND 4.0 International license .

Table 2: ROX trends comparing HFNT group with HFNT progressed to IMV group

\begin{tabular}{|l|l|l|l|l|l|}
\hline & N & Total & HFNT & $\begin{array}{l}\text { HFNT } \\
\text { progressed to } \\
\text { IMV }\end{array}$ & p-value \\
\hline ROX at HFNT initiation & 129 & $5.1(2.0)$ & $5.4(2.1)$ & $4.5(1.6)$ & 0.015 \\
\hline ROX at day 1 & 119 & $5.9(2.5)$ & $6.5(2.4)$ & $4.3(1.8)$ & 0.0001 \\
\hline ROX at day 2 & 101 & $6.9(3.1)$ & $7.2(3.2)$ & $5.2(2.1)$ & 0.017 \\
\hline ROX at day 3 & 98 & $8.1(4.1)$ & $8.4(4.2)$ & $5.2(1.9)$ & 0.0006 \\
\hline ROX at day 5 & 78 & $10.3(5.9)$ & $10.6(5.9)$ & $5.3(2.0)$ & 0.078 \\
\hline ROX at IMV & 40 & $3.4(1.0)$ & & $3.4(1.0)$ & $\mathrm{N} / \mathrm{A}$ \\
\hline $\begin{array}{l}\text { Mean ROX change per 24 } \\
\text { hours }\end{array}$ & 129 & $0.7(1.5)$ & $1.2(1.3)$ & $-0.3(1.2)$ & 0.0001 \\
\hline $\begin{array}{l}\text { Median ROX change per } \\
\text { 24 hours (IQR) }\end{array}$ & 129 & $0.5(0-1.5)$ & $1.2(0.3-1.7)$ & $0(-0.5-0.1)$ & 0.0001 \\
\hline
\end{tabular}


medRxiv preprint doi: https://doi.org/10.1101/2020.06.30.20143867; this version posted July 3, 2020. The copyright holder for this preprint (which was not certified by peer review) is the author/funder, who has granted medRxiv a license to display the preprint in perpetuity. It is made available under a CC-BY-NC-ND 4.0 International license .

Table 3: Other Outcomes comparing HFNT group with HFNT progressed to IMV group

\begin{tabular}{|l|l|l|l|l|}
\hline & Total (N=129) & \multicolumn{1}{|c|}{$\begin{array}{c}\text { HFNT only } \\
(\mathrm{N}=89)\end{array}$} & $\begin{array}{c}\text { HFNT } \\
\text { progressed to } \\
\text { IMV (N=40) }\end{array}$ & P-value \\
\hline $\begin{array}{l}\text { Days } \\
\text { to IMV }\end{array} \quad \begin{array}{c}\text { Mean } \\
\text { Median }\end{array}$ & $\begin{array}{l}2.5(3.3) \\
1(1.0-3.0)\end{array}$ & - & $\begin{array}{l}2.5(3.3) \\
1(1.0-3.0)\end{array}$ & $\begin{array}{l}\mathrm{N} / \mathrm{A} \\
\mathrm{N} / \mathrm{A}\end{array}$ \\
\hline Mortality & $29(22.5)$ & $10(11.2)$ & $19(47.5)$ & 0.0001 \\
\hline LOS & $14.0(8.0)$ & $11.1(4.7)$ & $19.5(9.9)$ & $<0.0001$ \\
\hline HAP/VAP & $11(8.6)$ & $1(1.1)$ & $10(25.0)$ & $<0.0001$ \\
\hline
\end{tabular}

*LOS- length of stay, HAP/VAP - hospital acquired pneumonia/ventilator acquired pneumonia 


\section{Table 4: Logistic Regression Model Predicting Need for IMV}

\begin{tabular}{|l|l|l|}
\hline Variable & Odds Ratio & P-value \\
\hline $\begin{array}{l}\text { ROX at HFNT initiation } \\
=<5 \\
>\mathbf{5}\end{array}$ & $\begin{array}{l}2.137 \\
1\end{array}$ & 0.0517 \\
\hline $\begin{array}{l}\Delta \text { ROX from baseline (any 24-hr period) } \\
\text { Decreased by 1 } \\
\text { Increased by 1 }\end{array}$ & 5 & 0.0001 \\
\hline $\begin{array}{l}\Delta \text { ROX change per day } \\
=<0 \\
>0\end{array}$ & 1 & \\
\hline $\begin{array}{l}\text { Pulmonary Vasodilators } \\
\text { Yes } \\
\text { No }\end{array}$ & 14.671 & 0.0001 \\
\hline \multicolumn{1}{|c|}{ Final Multivariate Model } \\
\hline
\end{tabular}

*Univariate model in supplementary 
Figure1: Consort Diagram for our screening

Figure 2: Average ROX index progression of HFNT group

compared to HFNT progressed to IMV group

Figure 3: Kaplan-Meier Comparing survival in HFNT group and

HFNT progressed to IMV group.

Figure 4: Kaplan-Meir showing intubation Free Survival probability

by ROX change per 24 hours.

Figure 5: ROC predicting need for IMV using $\triangle \mathrm{ROX}$ per 24 hours

Figure 6: ROC of multivariate model of $\triangle \mathrm{ROX}, \mathrm{D}$-Dimer and GFR to predict need for IMV 


\section{References:}

1. Guan W, Ni Z, Hu Y, et al. Clinical Characteristics of Coronavirus Disease 2019 in China. New England Journal of Medicine 2020;0: null.

2. COVID-19 Map; Johns Hopkins Coronavirus Resource Center. Anonymous.

(Accessed Apr 15, 2020, at https://coronavirus.jhu.edu/map.html).

3. Ziehr DR, Alladina J, Petri CR, et al. Respiratory Pathophysiology of Mechanically Ventilated Patients with COVID-19: A Cohort Study. Am J Respir Crit Care Med 2020.

4. Grasselli G, Zangrillo A, Zanella A, et al. Baseline Characteristics and Outcomes of 1591 Patients Infected With SARS-CoV-2 Admitted to ICUs of the Lombardy Region, Italy. JAMA 2020.

5. Bhatraju PK, Ghassemieh BJ, Nichols M, et al. Covid-19 in Critically III Patients in the Seattle Region - Case Series. New England Journal of Medicine 2020;0: null.

6. Yang $X, Y u Y, X u$ J, et al. Clinical course and outcomes of critically ill patients with SARS-CoV-2 pneumonia in Wuhan, China: a single-centered, retrospective, observational study. The Lancet Respiratory Medicine 2020.

7. Richardson S, Hirsch JS, Narasimhan M, et al. Presenting Characteristics, Comorbidities, and Outcomes Among 5700 Patients Hospitalized With COVID-19 in the New York City Area. JAMA 2020.

8. Arentz M, Yim E, Klaff L, et al. Characteristics and Outcomes of 21 Critically III Patients With COVID-19 in Washington State. JAMA 2020.

9. Wang D, Hu B, Hu C, et al. Clinical Characteristics of 138 Hospitalized Patients With 2019 Novel Coronavirus-Infected Pneumonia in Wuhan, China. JAMA 2020.

10. Alford RH, Kasel JA, Gerone PJ, Knight V. Human influenza resulting from aerosol 
inhalation. Proc Soc Exp Biol Med 1966; 122:800-4.

11. Zhou F, Yu T, Du R, et al. Clinical course and risk factors for mortality of adult inpatients with COVID-19 in Wuhan, China: a retrospective cohort study. Lancet 2020; 395:1054-62.

12. Ñamendys-Silva SA. Respiratory support for patients with COVID-19 infection. The Lancet Respiratory Medicine 2020;8: e18.

13. Yu C. Correspondence. British Journal of Surgery 2019; 106:949.

14. Kluge S, Janssens U, Welte T, Weber-Carstens S, Marx G, Karagiannidis C.

German recommendations for critically ill patients with COVIDQ19. Medizinische Klinik, Intensivmedizin und Notfallmedizin 2020.

15. Rello J, Pérez M, Roca O, et al. High-flow nasal therapy in adults with severe acute respiratory infection: a cohort study in patients with 2009 influenza A/H1N1v. J Crit Care 2012;27:434-9.

16. Frat J, Thille AW, Mercat A, et al. High-flow oxygen through nasal cannula in acute hypoxemic respiratory failure. N Engl J Med 2015; 372:2185-96.

17. Ou X, Hua Y, Liu J, Gong C, Zhao W. Effect of high-flow nasal cannula oxygen therapy in adults with acute hypoxemic respiratory failure: a meta-analysis of randomized controlled trials. CMAJ 2017;189: E260-7.

18. Rochwerg B, Granton D, Wang DX, et al. High flow nasal cannula compared with conventional oxygen therapy for acute hypoxemic respiratory failure: a systematic review and meta-analysis. Intensive Care Med 2019; 45:563-72.

19. Ferreyro BL, Angriman F, Munshi L, et al. Association of Noninvasive Oxygenation Strategies with All-Cause Mortality in Adults with Acute Hypoxemic Respiratory Failure: 
A Systematic Review and Meta-analysis. JAMA 2020.

20. Hernández G, Vaquero C, Colinas L, et al. Effect of Postextubation High-Flow Nasal

Cannula vs Noninvasive Ventilation on Reintubation and Postextubation Respiratory

Failure in High-Risk Patients: A Randomized Clinical Trial. JAMA 2016; 316:1565-74.

21. Hernández G, Vaquero C, González P, et al. Effect of Postextubation High-Flow

Nasal Cannula vs Conventional Oxygen Therapy on Reintubation in Low-Risk Patients:

A Randomized Clinical Trial. JAMA 2016; 315:1354-61.

22. Alhazzani W, Møller M, Arabi Y, et al. Surviving Sepsis Campaign: Guidelines on the Management of Critically III Adults with Coronavirus Disease 2019 (COVID-19).

Critical Care Medicine 2020;1.

23. Roca, Oriol, MD, PhD, Messika J, MD, Caralt B, MD, et al. Predicting Success of High Flow Nasal Cannula in Pneumonia Patients with Hypoxemic Respiratory Failure:

The Utility of the ROX Index. Journal of Critical Care 2016; 35:200-5.

24. Xu X, Yu C, Qu J, et al. Imaging and clinical features of patients with 2019 novel coronavirus SARS-CoV-2. Eur J Nucl Med Mol Imaging 2020; 47:1275-80.

25. Patel M, Gangemi A, Marron R, et al. Use of High Flow Nasal Therapy to Treat Moderate to Severe Hypoxemic Respiratory Failure in COVID-19. medRxiv 2020:2020.05.22.20109355.

26. Gattinoni L, Coppola S, Cressoni M, Busana M, Rossi S, Chiumello D. Covid-19 Does Not Lead to a "Typical" Acute Respiratory Distress Syndrome. American journal of respiratory and critical care medicine 2020 .

27. Gattinoni L, Chiumello D, Caironi P, et al. COVID-19 pneumonia: different respiratory treatments for different phenotypes? Intensive Care Medicine 2020. 
medRxiv preprint doi: https://doi.org/10.1101/2020.06.30.20143867; this version posted July 3, 2020. The copyright holder for this preprint (which was not certified by peer review) is the author/funder, who has granted medRxiv a license to display the preprint in perpetuity. It is made available under a CC-BY-NC-ND 4.0 International license .

28. Parke RL, McGuinness SP. Pressures delivered by nasal high flow oxygen during all phases of the respiratory cycle. Respir Care 2013; 58:1621-4.

29. Spence C, Spence C, Buchmann N, Buchmann N, Jermy M, Jermy M. Unsteady flow in the nasal cavity with high flow therapy measured by stereoscopic PIV. Exp Fluids 2012; 52:569-79.

30. The Acute Respiratory Distress Syndrome Network. Ventilation with Lower Tidal Volumes as Compared with Traditional Tidal Volumes for Acute Lung Injury and the Acute Respiratory Distress Syndrome. The New England Journal of Medicine 2000; 342:1301-8.

31. Wrigge H, Zinserling J, Stüber F, et al. Effects of Mechanical Ventilation on Release of Cytokines into Systemic Circulation in Patients with Normal Pulmonary Function. Anesthesiology 2000; 93:1413-7.

32. Huang C, Wang Y, Li X, et al. Clinical features of patients infected with 2019 novel coronavirus in Wuhan, China. The Lancet 2020; 395:497-506.

33. Fu B, Xu X, Wei H. Why tocilizumab could be an effective treatment for severe COVID-19? Journal of Translational Medicine 2020;18.

34. Marini JJ, Gattinoni L. Management of COVID-19 Respiratory Distress. JAMA 2020; 323:2329-30.

35. Tobin MJ, Laghi F, Jubran A. Caution about early intubation and mechanical ventilation in COVID-19. Annals of Intensive Care 2020; 10:78.

36. Roca O, Caralt B, Messika J, et al. An Index Combining Respiratory Rate and Oxygenation to Predict Outcome of Nasal High-Flow Therapy. American journal of respiratory and critical care medicine 2019; 199:1368-76. 
medRxiv preprint doi: https://doi.org/10.1101/2020.06.30.20143867; this version posted July 3, 2020. The copyright holder for this preprint (which was not certified by peer review) is the author/funder, who has granted medRxiv a license to display the preprint in perpetuity. It is made available under a CC-BY-NC-ND 4.0 International license .

37. Hill NS, Ruthazer R. Predicting Outcomes of High-Flow Nasal Cannula for Acute Respiratory Distress Syndrome. An Index that ROX. American journal of respiratory and critical care medicine 2019; 199:1300-2.

38. Ackermann M, Verleden SE, Kuehnel M, et al. Pulmonary Vascular Endothelialitis, Thrombosis, and Angiogenesis in Covid-19. New England Journal of Medicine 2020;0: null.

39. Raboud J, Shigayeva A, McGeer A, et al. Risk Factors for SARS Transmission from Patients Requiring Intubation: A Multicentre Investigation in Toronto, Canada. PLoS One 2010;5.

40. Leung $\mathrm{CCH}$, Joynt GM, Gomersall CD, et al. Comparison of high-flow nasal cannula versus oxygen face mask for environmental bacterial contamination in critically ill pneumonia patients: a randomized controlled crossover trial. Journal of Hospital Infection 2019; 101:84-7.

41. Kotoda M, Hishiyama S, Mitsui K, et al. Assessment of the potential for pathogen dispersal during high-flow nasal therapy. Journal of Hospital Infection 2020; 104:534-7. 42. Li J, Fink JB, Ehrmann S. High-flow nasal cannula for COVID-19 patients: low risk of bio-aerosol dispersion. Eur Respir J 2020;2000892.

43. Iwashyna TJ, Boehman A, Capelcelatro J, et al. Variation in Aerosol Production Across Oxygen Delivery Devices in Spontaneously Breathing Human Subjects. medRxiv 2020;2020.04.15.20066688. 


\section{Acknowledgements:}

Maulin Patel will be the corresponding author and guarantor for the manuscript. Maulin Patel, Matthew Gordon, Junad Chowdhury and Gerard J Criner formulated the overall study design. Huaqing Zhao, Nicole Patlakh, Maulin Patel, Andrew Gangemi, Robert Marron, Junad Chowdhury, Nicole Mills, Zachariah Dorey-Stein, Ibraheem Yousef, Lauren Tragesser, Julie Giurintano assisted in data collection, consolidation and analysis. Maulin Patel, Junad Chowdhury, Parth Rali, Rohit Gupta, Gilbert D'Alonzo and Matthew Gordon drafted the manuscript. Gerard J Criner and Matthew Gordon revised and reviewed the Manuscript 


\section{Figure1: Consort Diagram for our screening}

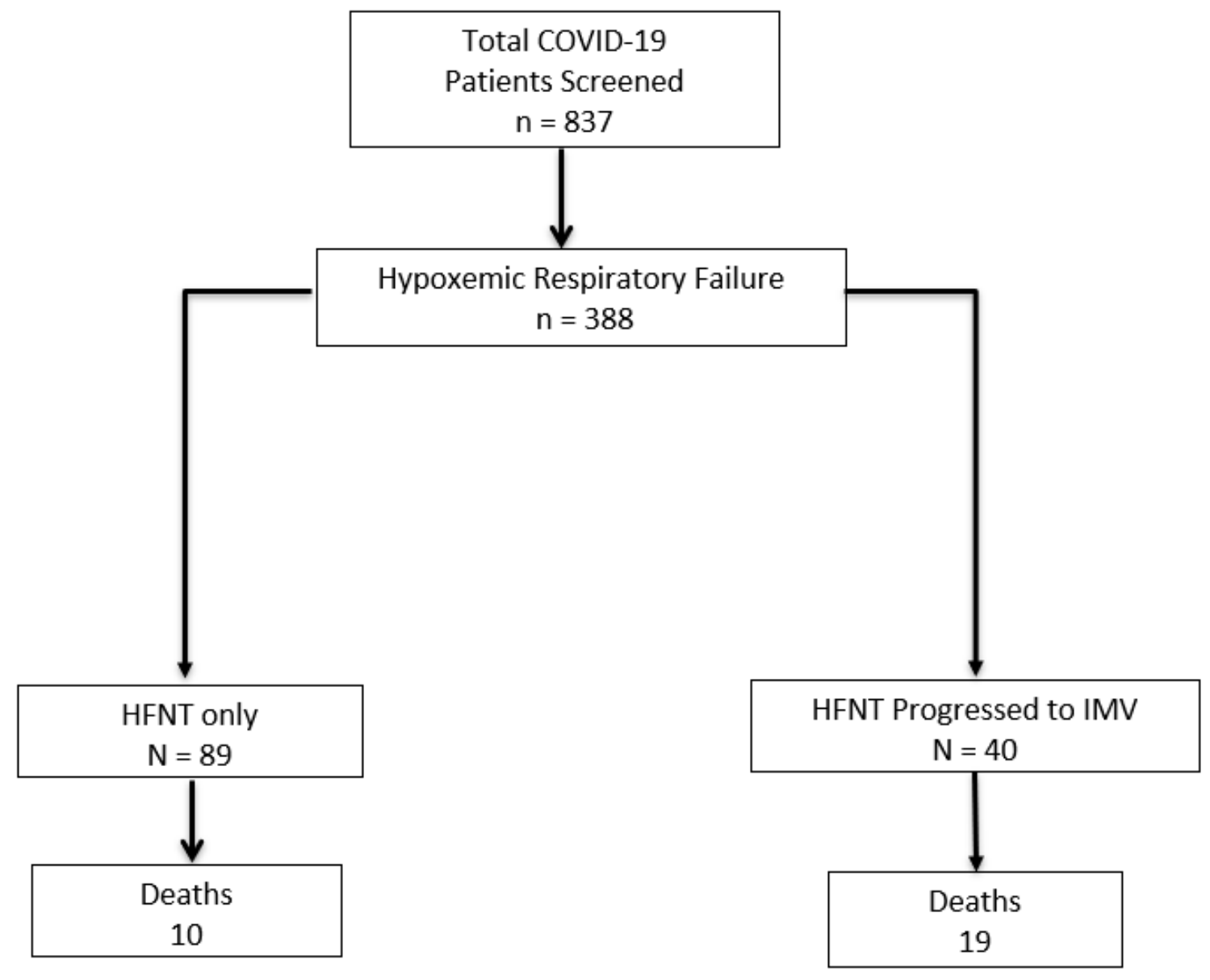


Figure 2: Average ROX index progression of HFNT group compared to HFNT progressed to IMV group

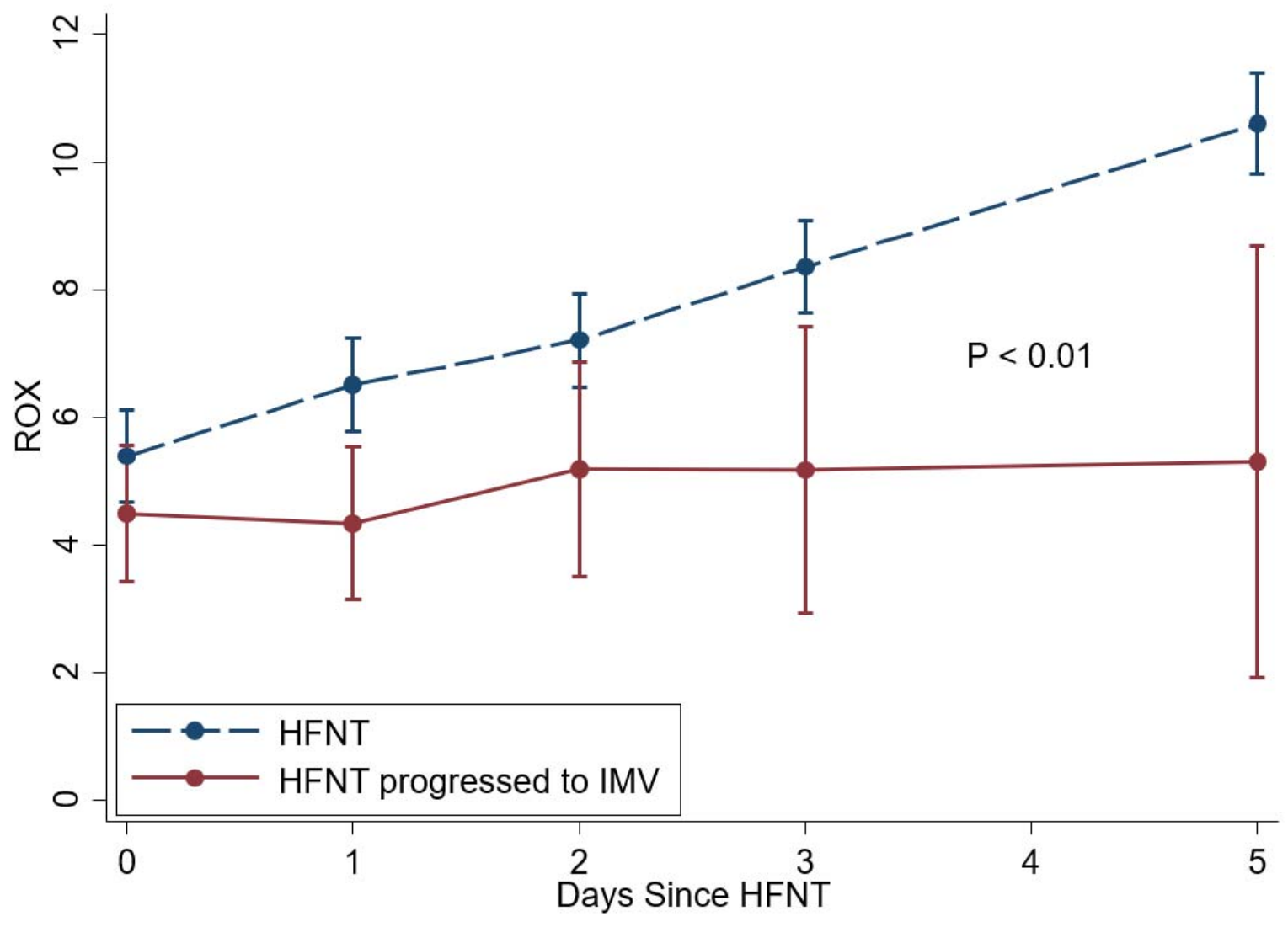


Figure 3: Kaplan-Meier Comparing survival in HFNT group and HFNT progressed to IMV group.

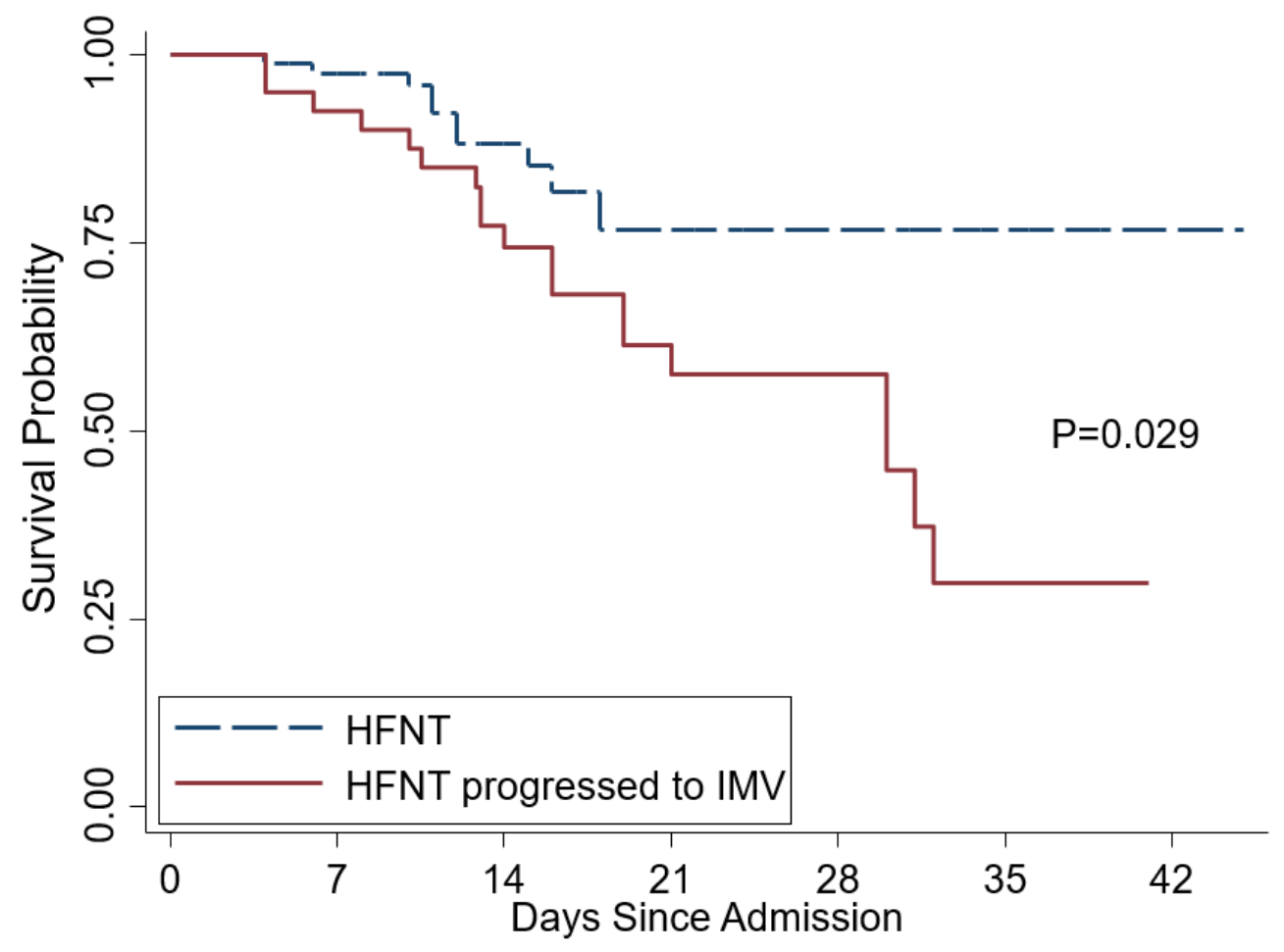

Number at risk

HFNT 89

78

37

37

27

10

5

11

$\begin{array}{ll}3 & 1 \\ 4 & 0\end{array}$


Figure 4: Kaplan-Meir showing intubation Free Survival probability

\section{by ROX change per 24 hours.}

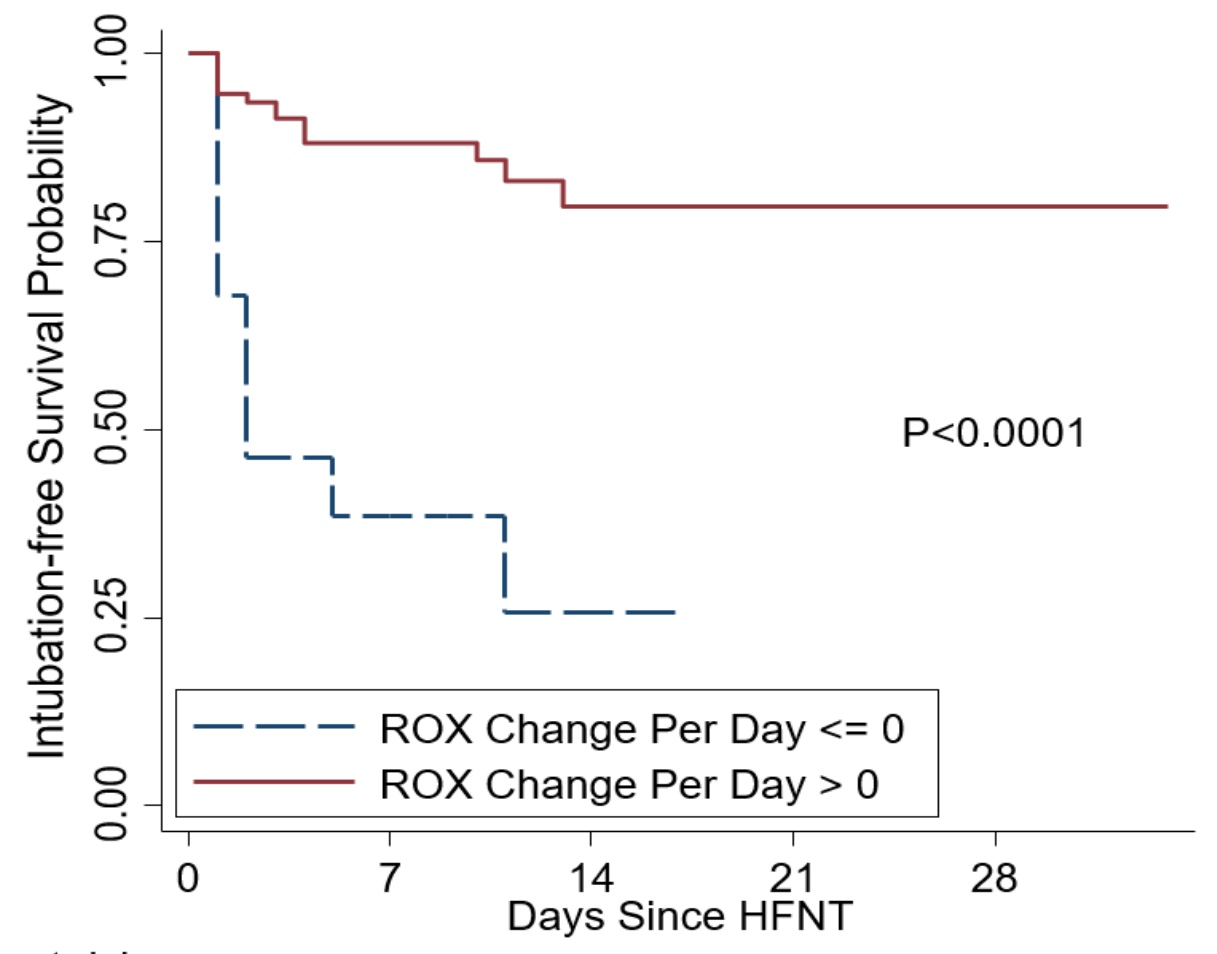

Number at risk

ROX Change Per Day $<=028$

ROX Change Per Day > 093

8

1
17

0

0

60

17

8

5 


\section{Figure 5: ROC predicting need for IMV using $\triangle \mathrm{ROX}$ per 24 hours}

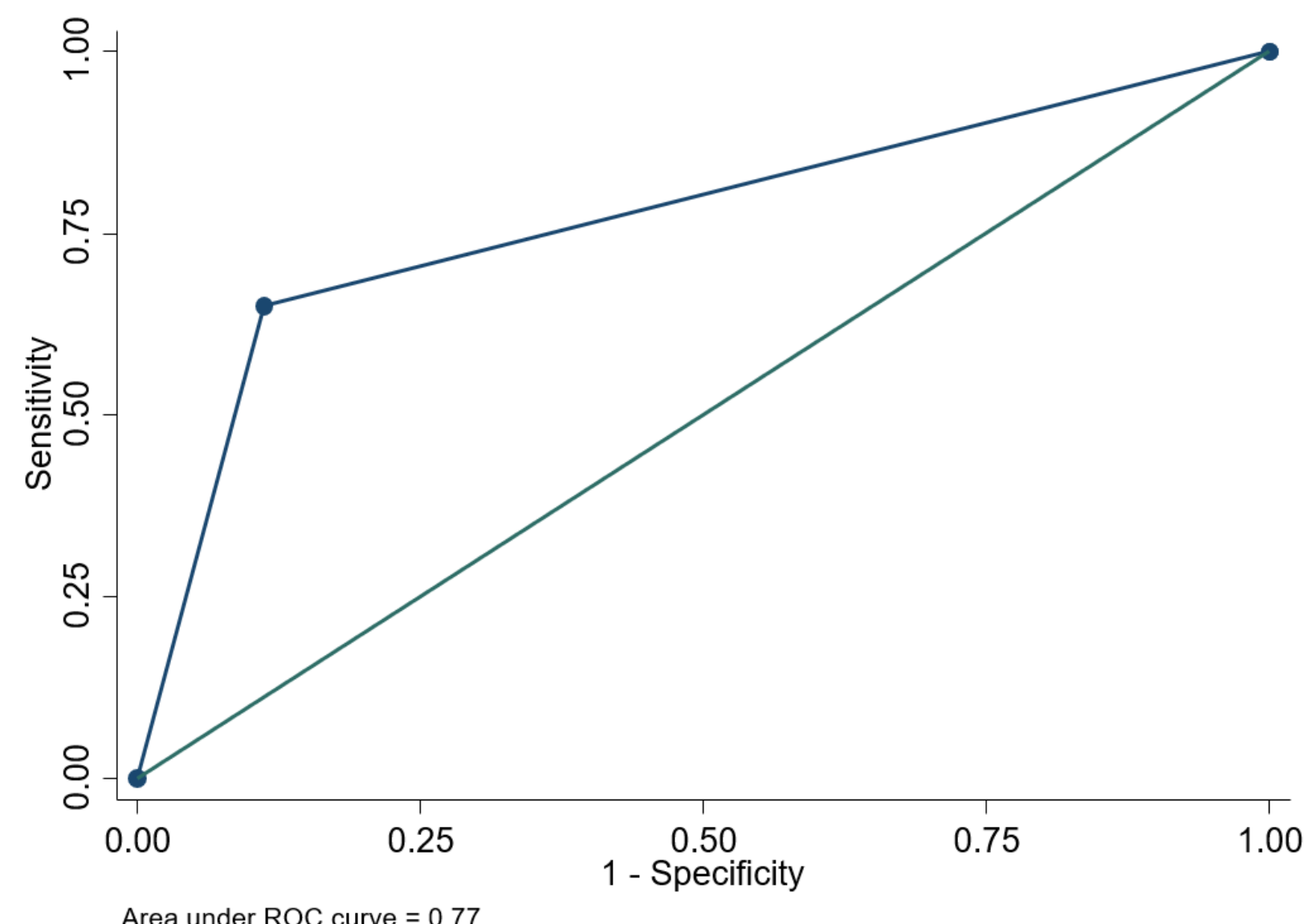

Area under ROC curve $=0.77$ 
Figure 6: ROC of multivariate model of $\triangle \mathrm{ROX}$, D-Dimer and GFR

\section{to predict need for IMV}

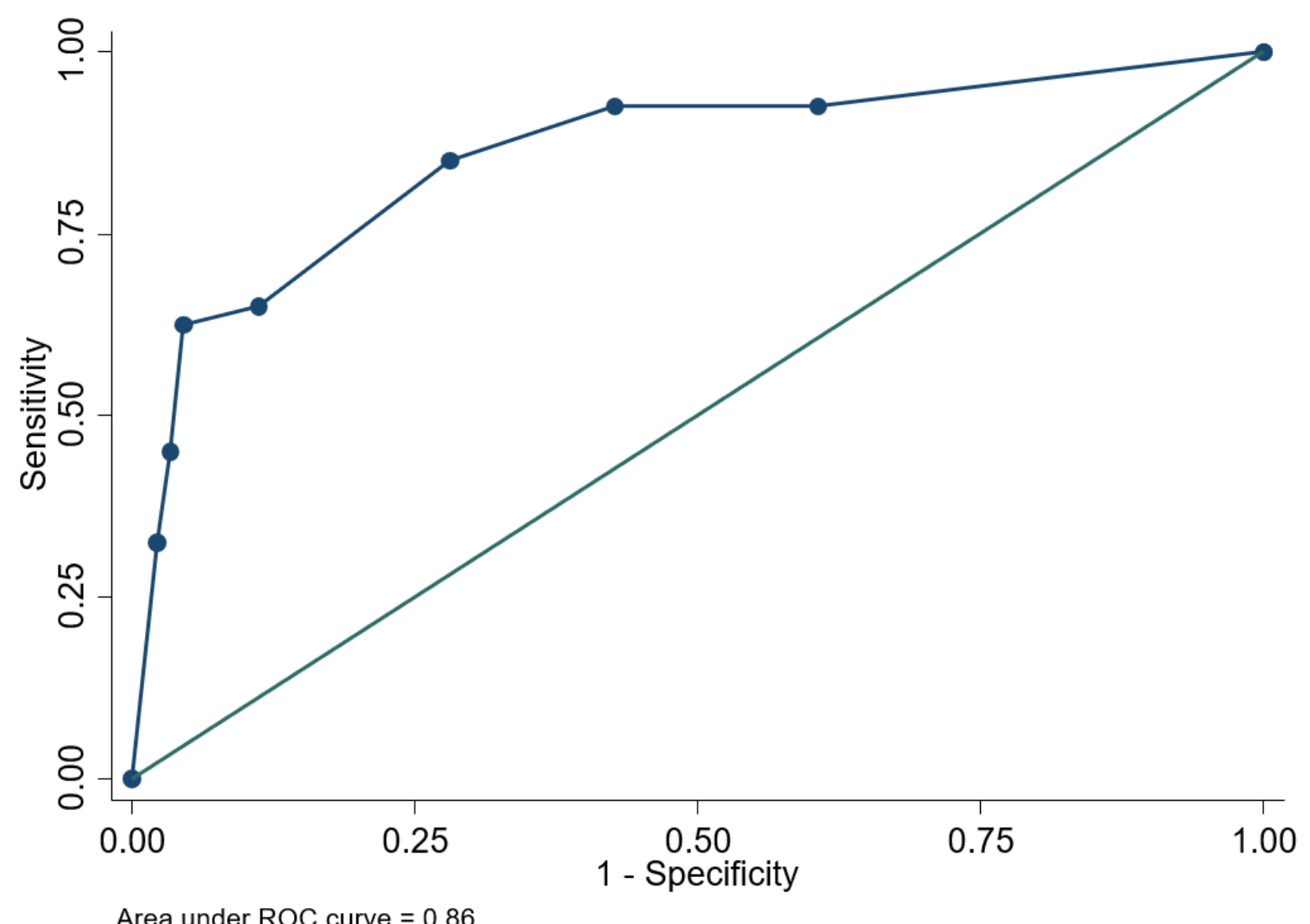

Area under ROC curve $=0.86$ 